\title{
ガラスの電解によるイオン交換
}

\author{
太田 博 紀*・原 守 久** \\ (* 旭硝子 (株) 研究所 $* *$ 旭硝子 (株) 船橋工場)
}

\section{Ion-Exchange in Sheet Glass by Electrolysis}

\author{
By \\ Hironori OHTA* and Morihisa HARA** \\ (* Asahi Glass Co., Ltd., Research Laboratory, Yokohama, \\ ** Asahi Glass Co., Ltd., Funabashi Factory, Funabashi.
}

The ion-exchange process was investigated by electrolyzing potassium ions into commercial sheet glass below its strain point. The concentration of potassium ions diffused into the glass sheet under the electric field gave a rectangular profile. The analytical measurements showed that no more than $93 \%$ of sodium ions were replaced by the potassium ions.

The apparent resistivity $\rho$, increased linearly with the increase of thickness $\varepsilon$ of the ion-exchanged layer, as expressed in the equation, $\rho=\rho_{0}+\rho_{1} \varepsilon / L$, where $L$ is the thickness of the glass sheet, $\rho_{0}$ and $\rho_{1}$ are resistivities related to the diffusion of sodium ions and potassium ions in the sheet glass respectively. The activation energy for conductivity due to those ions was obtained from the temperature dependence of $\rho_{0}$ and $\rho_{1}$. The potassium diffusion coefficient in the sheet glass was estimated from the Einstein relation by use of an assumed correlation factor.

The stress profile in the layer was measured by means of a polarization microscope with the aid of a Berek compensator. The compressive stress increased appreciably with the depth of the ion-exchanged layer and abruptly changed into the tensile stress at the boundary of the layer. The characteristics of the stress profile were explained by the different degree of stress relaxation which is greater at the layer nearer to the surface.

When potassium ions were diffused into one side of a glass sheet, the sheet was bent in order to balance stresses due to the ion-exchange. The stresses in the layer calculated from the curvature of the bend were not changed with the temperature of the treatment and became fairly larger than the observed values when the sheet was treated at higher temperatures, because the curvature was not affected by stress relaxation.

[Received Nov. 24, 1969]

\section{1. 緒言}

徐冷域以下の温度で, ガラスに含まれているアルカリ イオンを，より大きいアルカリイオンで置換させ，ガラ スの表面に圧縮応力層を形成させる方法はよく知られて かる．通常は，該アルカリイオンを含む熔融塩中にガラ スを浸漬させ，自然拡散によりイオン交換を行なわせ る.しかし，この工程を普通板ガラスに適用すると，十 分な量のイオン交換を行なわせるのには，多大の時間を 要する.このため, 印加電圧の下にイオン交換を強制的 に行なわせ，交換時間を短縮させようとする試みがあ $3^{1)}$.

著者は，普通板ガラスを電解により $\mathrm{Na}^{+} \rightarrow \mathrm{K}^{+}$イオ ン交換させたときの $\mathrm{K}^{+}$イオン濃度分布, 応力分布, 交 換中のガラスの抵抗変化などを測定した. 片面のみ応力 が作用すると，その板は验り合いのために球面状に弯曲
するが，その曲率から応力を算出することができる．こ れら種々の測定結果より, 電解によるイオン交換のメカ ニズム，応力緩和などを考察した.

\section{2. ガラスの電解と侵入イオン濃度の理論式}

珪酸塩ガラスに㧍ける電気伝導の過程は, 次のように 考えられている. 低温では, ガラス中の珪素と酸素から 成る四面体の網目構造は固定されているが，網目修飾イ オンとしての金属イオンの結合注らるく，網目構造の比 較的大きな穴 (cavity) に存在して熱振動を行なってい る.この金属イオンが究から穴へジャンプして, 電気を 伝導するが，严る電場の下で生じる電流は，network cavity を通じて漂らこれらイオンを統計的に扱らことに より計算される.

いま，拡散に抬ける Fick の第 2 法則 
17 太田博紀ほか

$$
\frac{\partial c}{\partial t}=D \frac{\partial^{2} c}{\partial x^{2}}
$$

を半無限大の媒質 $(0 \leq x<\infty)$ について, 次の境界条 件

$$
c=c_{0}(=\text { const. }), x=0, t>0,
$$

と次の初期条件

$$
c=0, x>0, t=0
$$

で解くと，

$$
c=c_{0} \operatorname{erfc}\left(\frac{x}{2 \sqrt{D t}}\right)=c_{0}\left(1-\frac{2}{\sqrt{\pi}} \int_{0}^{\frac{x}{2 \sqrt{D t}}} e^{-\eta^{2}} d \eta\right)
$$

が得られる．ここで， $c_{0}$ は始めにガラス中に含まれてい た $\mathrm{Na}^{+}$イオンの濃度に等しいとする.

次に, 一定電場の下での拡散方程式は, 電場の強さを $F$ volt $/ \mathrm{cm}, \mathrm{K}^{+}$イオンの易動度をvとして,

$$
\frac{\partial c}{\partial t}=D \frac{\partial^{2} c}{\partial x^{2}}-F v \frac{\partial c}{\partial x}
$$

となる.これを先の境界条件と初期条件のもとに解くと

$$
c=c_{0} \operatorname{erfc}\left(\frac{x-F v t}{2 \sqrt{D t}}\right)=c_{0}\left(1-\frac{2}{\sqrt{\pi}} \int_{0}^{\frac{x-F v t}{2 \sqrt{D t}}} e^{-\eta^{2}} d \eta\right)
$$

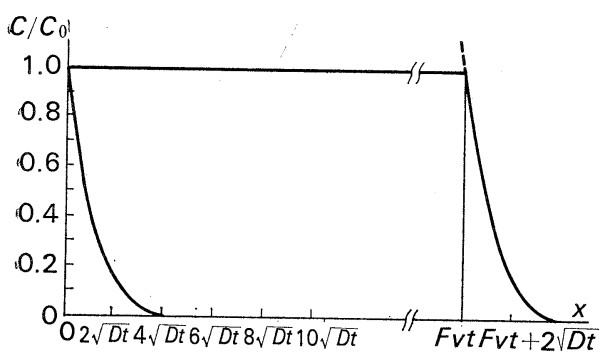

Fig. 1. Concentration-distance curves calculated from the diffusion eq.

となる。(1)，(2) 式より，それぞれ 自然拡散および印加 電圧下での拡散に括ける $\mathrm{K}^{+}$イオン濃度分布を 図-1 に 示す.（2) 式は (1) 式を $x$ の正方向に $F v t$ だけ平行移 動した図になるが， $\mathrm{K}^{+}$イオンの濃度は始めにガラス中 に存在していた $\mathrm{Na}^{+}$イオンの濃度 $c_{0}$ より高くなること はないので, $0 \leq x<F v t$ では， $c=c_{0}$ となる. $x \geq F v t$ における濃度分布は自然拡散によるものである. 実際に は, $F v t \gg \sqrt{D t}$ であるため, 印加電圧下では $x>F v t$ の部分は無視できて, $\mathrm{K}^{+}$イオンの濃度分布図は矩形状 になる。

このことから，いま，ガラス中の始めの $\mathrm{Na}^{+}$イオン 濃度を $c_{\mathrm{Na}}\left(\mathrm{g} / \mathrm{cm}^{3}\right)$ とし， $Q\left(\right.$ coulomb $\left./ \mathrm{cm}^{2}\right)$ の電気量を 流したとき，ガラスの陽極側の面に深さ $\varepsilon(\mathrm{cm})$ だけす ベての $\mathrm{Na}$ イオンが $\mathrm{K}^{+}$イオンに置換されたとすれば， Faraday の法則より，

$$
\varepsilon=\frac{23}{96500} \cdot \frac{Q}{c_{\mathrm{Na}}}
$$

窯業協会誌 78 [5] 1970159

一方, 電解前後のガラス の重量差を $\Delta W\left(\mathrm{~g} / \mathrm{cm}^{2}\right)$ とす れば, $\varepsilon(\mathrm{cm})$ の交換層の中では全ての $\mathrm{Na}^{+}$イオンは $\mathrm{K}^{+}$ イオンで置換されているのだから,

$$
\varepsilon=\frac{23}{16} \cdot \frac{\Delta W}{c_{\mathrm{Na}}}
$$

となる. 故に, 通電量がわかれば (3) 式を用いて, 重量 差がわかれば (4) 式を用いて交換層の厚さ $\varepsilon$ が計算で きる.しかし，第 4 節で述べるように， $\mathrm{K}^{+}$イオンの濃度 分布の測定結果では, 全アルカリ成分は $\mathrm{K}^{+}$イオンで置 換されていないため，実際の交換層の厚さは，上記の計 算值より若干大きくなる．また，実験中に leak current などにより通電量の全部がイオン交換に使われない場合 には, $\varepsilon_{Q}>\varepsilon_{W}^{i}\left(\varepsilon_{Q}\right.$ は (3) 式による $\varepsilon, \varepsilon_{W}$ は (4) 式によ る $\varepsilon$ ) となるが,*実験結果で注両者は数\%内でよく一致 した.

\section{3. 電 解 方 法}

本実験では，硝酸カリウムと粘土に水を加えてペース ト状に混合したものを板ガラスの両面に塗布し，乾燥炉 内で十分に乾燥させてから実験を行なった。粘土には ocher を用い，硝酸カリウムは乳鉢で微粉に摩砕してか ら粘土と均一になるよらによく混合した．電極は界面抵 抗が少なく，しかもガラス面を污染させないものとし て，グラファイト・ブロックを採用した．電極への導線 としては，ステンレス棒を用いた，実験装置の概略図を 図-2 に示す. ガラス試料は， $3 \mathrm{~mm}$ 厚で $5 \mathrm{~cm}$ 角あるい は径 $5 \mathrm{~cm}$ の円形の並板を用いた．電気炉はニクロム線 電気炉を用い，電子管式調節計により温度を制 御した が,比抵抗測定の実験では,ガラスの抵抗がわずかな温度 変動にも影響されるため, 手動により設定温度の $\pm 1^{\circ} \mathrm{C}$ 以内におさめるようにした。

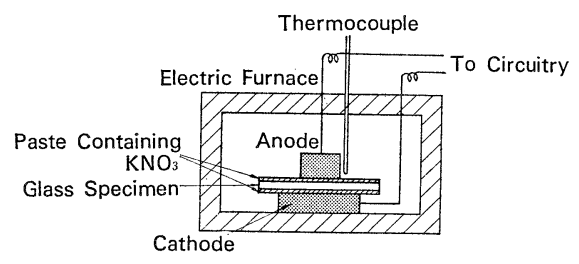

Fig. 2. Schematic diagram of apparatus for electrolysis.

\section{4. $\mathbf{K}^{+}$イオンの濃度分布の測定}

電解によりガラス中に侵入した $\mathrm{K}^{+}$イオンは，ガラス の断面方向に対しどのような濃度分布を持しているのか を知ることは，応力分布や強度を，また抵抗值変化を理 解するらえにきわめて興味ある問題である. 本実験で は，炎光分析により濃度を測定した．この方法は，試料 板の片面を密蝻によりエッチングから遮蔽し，もら一方 の調ベる面のみエッチングされるようにした。エッチン 


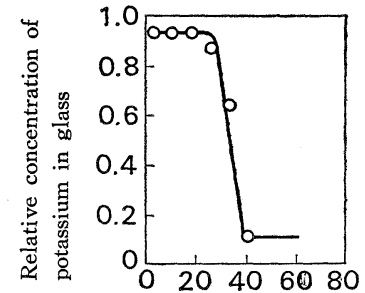

Distance in micron

Fig. 3. Profile of potassium in glass electrolyzed at $420^{\circ} \mathrm{C}$ and $99 \mathrm{~V} / \mathrm{cm}$ for $108 \mathrm{~min}$.

グ液は $4 \%$ の弗酸と $4 \%$ の硫酸の混合液を用い，エッチ ングされた層の厚み $d$ は，エッチング前後の重量差 $\Delta$ $W$ と次式から算出した。

$$
\rho_{0} A d=\Delta W-\left(m_{\mathrm{K}}-\frac{\rho_{0} A d m_{\mathrm{K}}^{\prime}}{M_{\mathrm{K}_{2} \mathrm{O}}} \times 2\right)\left(M_{\mathrm{K}}-M_{\mathrm{Na}}\right)
$$

$\rho_{0}$ はイオン交換前のガラスの密度，A はエッチングさ れた表面積， $m_{\mathrm{K}}$ はエッチングされた層中の $\mathrm{K}^{+}$イオン のモル数, $m^{\prime} \mathrm{K}$ は交換前のガラス中に含まれていた $\mathrm{K}^{+}$ イオンの重量 $\%, M$ は分子量である.

結果を図-3に示す.この図をみると，K+イオン濃度 は，30〜 40 $\mu$ で急激に減少し，第 2 節で述べた近似をよ く満足している.しかし，ガラス中のアルカリ成分は全 部 $\mathrm{K}^{+}$イオンで置換されず,その約 $93 \%$ しか $\mathrm{K}^{+}$イオン は占めていない.この值は, D.L. Rothermel が $\mathrm{SiO}_{2}$ ・ $\mathrm{Al}_{2} \mathrm{O}_{3} \cdot \mathrm{R}_{2} \mathrm{O}$ 系ガラスにおいて, 自然拡散によるイオン交 換で得られた表面の $\mathrm{Na}^{+}$イオンあるいは $\mathrm{K}^{+}$イオンの 最高濃度の值，90９2\% と comparable な值である ${ }^{2)}$.

\section{5. 電解中の抵抗値変化}

ガラス中での $\mathrm{K}^{+}$イオンの mobility は, $\mathrm{Na}^{+}$イオン より小さいため, 電解により $\mathrm{K}^{+}$イオンがガラス中に入 って行くと, そのガラスの比抵抗は侵入した $\mathrm{K}^{+}$イオン の量に依存して変化していくことは想像に難くない. い ま, 侵入した $\mathrm{K}^{+}$イオン量とそのガラスの比抵抗は 1 次 関係にあると仮定して, ガラスの電場方向の厚さを $L$, 侵入した $\mathrm{K}^{+}$イオン層の厚みを $\varepsilon$ とたとき，ガラスの 比抵抗 $\rho$ を

$$
\rho L=\rho_{0}(L-\varepsilon)+\rho_{1} \varepsilon
$$

とおく.すなわち， $\rho_{0}$ は $\mathrm{Na}^{+}$イオンの mobility に関係 した量であり， $\rho_{1}$ は $\mathrm{K}^{+}$イオンの mobilityに依存した

Layer of Penetration of Potassium lons

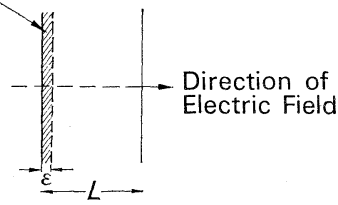

Fig. 4. Cross section of glass specimen.
量である(図-4 参照).ここで, $L \gg \varepsilon$ であるから，(6) 式をさらに簡単化すると,

$$
\rho=\rho_{0}+\frac{\rho_{1}}{L} \varepsilon
$$

となる。

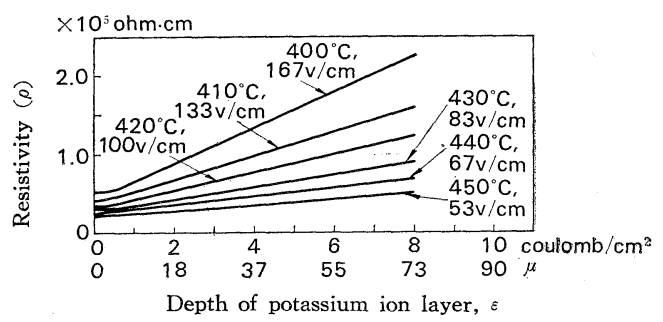

Fig. 5. Resistivity as a function of thickness of ion-exchanged layer at various temperatures and fields.

各温度における通電量 ( $\mathrm{K}^{+}$イオン層の厚み) に対す る比抵抗変化の 測定結果を図 -5 に示した. これらのグ ラフは，いずれも 4 5 個のデータの平均をとったもの であり，Joule 熱やその他の影響を考慮して各温度とも ほぼ同程度の電流が流れるように電圧を定めた。これら のグラフをみると，どれも(7) 式を満足しており，低温 になるにつれて比抵抗は高く勾配す急になっている。一 般に, 誘電体においては, 通電直後は吸収電流の減少に 伴い抵抗值は時閒と共に増加する傾向がみられるが，図 -5 では，初期は逆に抵抗が下がっている。これは，吸収 電流がきわめて小さく，Joule 熱の発生によりガラスの 温度が上昇したために抵抗が減少する効果の方が大きい 結果と思われる. したがって, 高温ほど抵抗の減少効果 は小さい. 吸収電流がきわめて小さい事実は, 塗布塩に 硝酸ナトリウム塩を用い, 低電場における Joule 熱の発 生が小さいときのガラスの電気抵抗を測定した結果をみ ると明らかである.図-6にこの結果を示してある.ここ で, 電場の方向を数回逆転しても, 吸収電流は可逆であ り，それによる比抵抗の変化はわずか $0.02 \times 10^{5} \Omega \cdot \mathrm{cm}$, 飽和抵抗值の $3.6 \%$ にすぎない. したがって, 図 -5 に示 されている抵抗変化においては, 吸収電流の影響は誤差

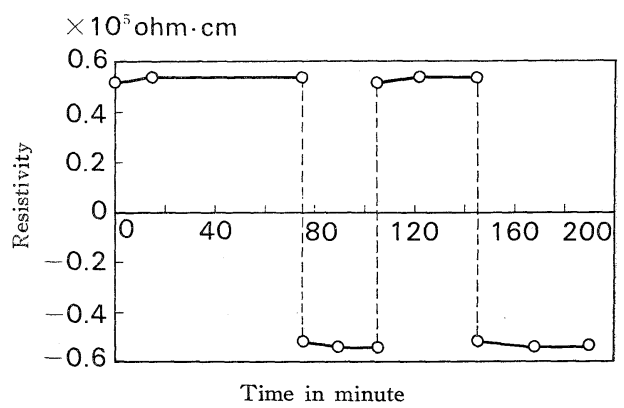

Fig. 6. The variation of resistivity of glass with time in an alternating D.C. field at $385^{\circ} \mathrm{C}$ and $43 \mathrm{~V} / \mathrm{cm}$. 
範囲に含まれているといってよい．

図-5において, 比抵抗の初期值は直線的な抵抗変化の 延長線上に乗らず，これより高い值を有している.一般 に，第 6 節で述べるように，ガラス中に $\mathrm{K}^{+}$イオンが侵 大すると，流動変形により network cavity は押し広げ られる.とくに, 通電直後は Joule 熱によりガラスの温 度は周囲より高くなるが，その後は炉内の設定温度に等 しくなるために，流動変形は初期は大きくなる．このた め，その部分が寄与する抵抗は小さくなり，初期值の方 が延長線上より高くなったと考えられる。これは，また 図-5において，低温ほど初期值と延長線とのずれが大き くなっていることからも裏付けられる. 以上から，(7) 式の $\rho_{0}$ の值は, 延長線上の切点よりは, 初期值の方が 正しいといえる.

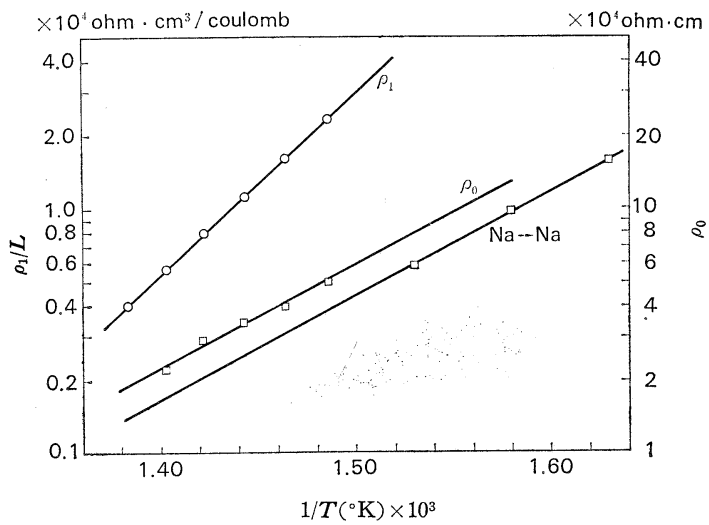

Fig. 7. The variation of $\rho_{0}, \rho_{1}$ and resistivity of $\mathrm{Na}^{+} \rightarrow \mathrm{Na}^{+}$ion-exchanged glass with temperature. Circles : $\rho_{1}$; Rectangles : $\rho_{0}$.

次に, 図-5の直線の傾き $\rho_{1}$ と比抵抗の 初期值 $\rho_{0}$ の 対数を絶対温度の逆数に対してプロットした直線を図一 7 に示す. $\rho_{1}, \rho_{0}$ ともよい直線性を示している. 先に述 ベたように， $\rho_{1}$ は $\mathrm{K}^{+}$イオンの mobilityに関係した量 であるから，この直線の傾きは，ガラス中での $\mathrm{K}^{+}$イオ ンの拡散の活性化エネルギーを表していると考えられ， これを計算すると $34.6 \mathrm{kcal} / \mathrm{mol}$ となる.この $\rho_{1}$ はま た，ガラスの $\mathrm{K}^{+}$イオン層の比抵抗でもあるから，Einstein の式 $D=R T / \rho c F^{2}$ よりガラス中の $\mathrm{K}^{+}$イオン の拡散係数を求めると, $450^{\circ} \mathrm{C}$ では, 仮に correlation factor 0.3 として ${ }^{3)}, D=1 \times 10^{-10} \mathrm{~cm}^{2} / \mathrm{sec}$ となる.こ れは P. LeClerk の值 $1 \times 10^{-11} \mathrm{~cm}^{2} / \mathrm{sec} と^{4)}$, ガラス組 成の違いを考慮すれば, reasonable な值である.

図-7には, 比較のため狳布塩に硝酸ナトリウムを用い た $\mathrm{Na}^{+} \rightarrow \mathrm{Na}^{+}$イオン交換の場合の比抵抗もプロットし てある. $\mathrm{Na}^{+} \rightarrow \mathrm{Na}^{+}$交換の抵抗は，ガラスの通常の抵 抗值であり，これについては多くの人たちが実験してい る.この場合の活性化エネルギーは $19.1 \mathrm{kcal} / \mathrm{mol}$ とな り，他の実験データ ${ }^{5}$ とよく一致している. この比抵抗
直線と $\rho_{0}$ の直線の傾きはほとんど等しく， $\rho_{0}$ の活性化 エネルギーは $18.9 \mathrm{kcal} / \mathrm{mol}$ である。このことから， $\rho_{0}$ は先に $\mathrm{Na}^{+}$イオンの mobility に関係した量と定義した こととよく一致する.一般には，この初期值は吸収電流 の影響を受け，ここで述べた $\mathrm{Na}^{+}$イオンの mobilityに 関係した值は得られ難い。しかし，先の図-6で述べた よらに, この場合, 吸収電流は微小であるため, その影 響無視して差し支えない。

以上から, 通電量に対する比抵抗の変化は, 図 -5 より 先に述べた近似式 (7) をよく満足し，しかも， $\rho_{0} ， \rho_{1}$ も 先に仮定したことの正しいことが，図-7より証明され た.

\section{1 応力分布の理論式}

\section{*6. 応力 分 布}

イオン交換により生じる応力值は，熱応力の計算方法 を用いて求めることができる.ここで, 温度差から生じ る歪による応力 $\alpha E T(z)(\alpha$ は膨脹係数， $E$ はヤング 率, 温度 $T$ は板厚 $z$ 方向の函数)の代りに, $\mathrm{K}^{+}$イオン 濃度から生じる歪による応力 $\phi(z)$ で置き換えねばなら ない.いま. 図-8のような任意の形で一定の厚さ $2 h$ の ガラス板を考え， $\mathrm{K}^{+}$イオン濃度は, 図-9 のような断面 方向の分布をしていると仮定する. $\mathrm{K}^{+}$イオン濃度が $c_{0}$ のときの歪から生じる応力を $\phi_{0}$ とすると, 熱忍力の式 から次式が導かれる ${ }^{6}$.

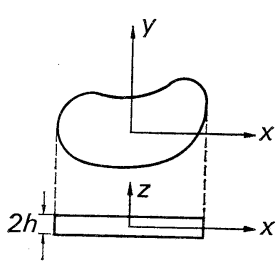

Fig. 8. Plate of arbitrary plane form and of constant thickness.

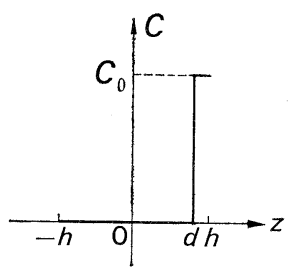

Fig. 9. Distribution of potassium concentration in glass.

$$
\begin{aligned}
& -h \leq z<d \text { では } \\
& \sigma=\sigma_{x x}=\sigma_{y y}=\frac{\phi_{0}}{1-\nu}\left\{\frac{h-d}{2 h}+\frac{3 z}{4 h^{3}}\left(h^{2}-d^{2}\right)\right\} \\
& \sigma_{z z}=\sigma_{x z}=\sigma_{y x}=\sigma_{z y}=0 \\
& d \leq z \leq h \text { では } \\
& \sigma=\sigma_{x x}=\sigma_{y y}=\frac{\phi_{0}}{1-\nu}\left\{-1+\frac{h-d}{2 h}+\frac{3 z}{4 h^{3}}\left(h^{2}-d^{2}\right)\right\} \\
& \sigma_{z z}=\sigma_{x z}=\sigma_{y x}=\sigma_{z y}=0
\end{aligned}
$$

このとき，板は釣り合いのために変形して，一 $h$ 側がロ になるように弯曲する. $1 / R_{x}, 1 / R_{y}$ をそれぞれ $x z, y z$ 平面に平行な断面における中立面の曲率とすると，

$$
\frac{1}{R_{x}}=\frac{1}{R_{y}}=\frac{3 \phi_{0}}{4 E} \frac{h^{2}-d^{2}}{h^{3}}
$$




$$
\therefore \phi_{0}=\frac{1}{R} \cdot \frac{4 E h^{3}}{3\left(h^{2}-d^{2}\right)}, R=R_{x}=R_{y}
$$

が導かれる7). したがって，(8) 式と (9) 式より，ガラ スの忘力值は, ガラス試料の曲率がわかれば求められ る. すなわち，(9)式を(8) 式に代入して $\phi_{0}$ を $R$ に置 きかえればよい。このとき，

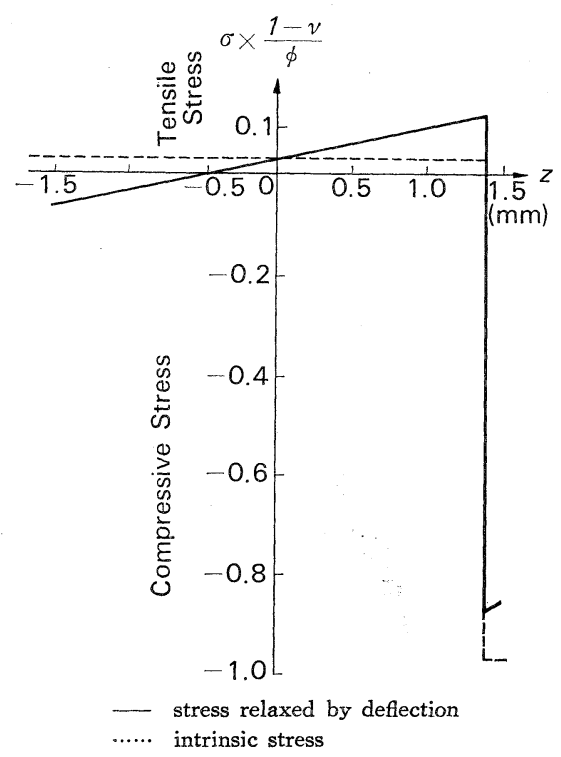

Fig. 10. Stress profiles in glass calculated from the equations of thermal stresses.

$$
\left.\begin{array}{l}
-h \leq z<d, \\
\quad \sigma=\frac{1}{1-\nu} \cdot \frac{2 E h^{2}}{3(h+d)} \cdot\left\{1+\frac{3 z}{2 h^{2}}(h-d)\right\} \cdot \frac{1}{R} \\
d \leq z \leq h, \\
\sigma=\frac{1}{1-\nu} \cdot \frac{2 E h^{2}}{3(h-d)} \cdot\left\{-1+\frac{3 z}{2 h^{2}}(h-d)\right\} \cdot \frac{1}{R}
\end{array}\right\}
$$

となる.（8）式より，計算による片面強化のときの応力 分布を図-10に示す. この図をみると，イオン交換側の 表面は応力値が若干減少しているが，これは板の変形に よるためである.また (9) 式より， $h-d=\varepsilon$ (ここでは $\varepsilon$ は交換層の厚多に等しい）とおくと，

$$
\frac{E}{6 \phi_{0}} \cdot \frac{(2 h)^{3}}{R}=\varepsilon(2 h-\varepsilon)
$$

となり，ガラスの板厚の 3 乘を曲率半径 $R$ で除した值 と，交換層の厚みとは 2 次式の関係があることを示して いる.

（8）式に打ける応力值は，板の変形後の值であり，実 際にイオン交換によって生じた值より，変形による緩和 のため小さくなっている・いま, 曲率 $1 / R$ まで板を曲げ たときの応力を $\sigma^{\prime}{ }_{x x}, \sigma^{\prime}{ }_{y y}$ とすれば,

$$
\sigma^{\prime}=\sigma^{\prime}{ }_{x x}=\sigma^{\prime}{ }_{y y}=\frac{E z}{(1-\nu) R}
$$

である.この $R$ に (9) 式の $\phi_{0}$ を代入して，

$$
\sigma^{\prime}=\frac{3}{4} \phi_{0} \frac{\left(h^{2}-d^{2}\right) z}{(1-\nu) h^{3}}
$$

となる．故に，板の曲がりによって緩和される応力值が (12) 式で与えられるから，イオン交換により生じる真の 応力值 $\sigma_{\text {int }}$ は, (8) 式から (12) 式を差引いた值とな る。

$$
\left.\begin{array}{rl}
-h & \leq z<d \\
\sigma_{\text {int }} & =\sigma-\sigma^{\prime}=\frac{\phi_{0}}{1-\nu} \cdot \frac{h-d}{2 h} \\
d \leq z & \leq h \\
\sigma_{\text {int }} & =\sigma-\sigma^{\prime}=-\frac{\phi_{0}}{1-\nu} \cdot \frac{h+d}{2 h}
\end{array}\right\}
$$

(13) 式の真の応力値の分布状態は, 図-10 に点線で示し てある

\section{2 偏光顕微鏡により測定した応力分布}

イオン交換した試料から，精密切断機で厚さ $0.3 \mathrm{~mm}$ の断面方向の薄片を切り取り, 偏光顕微鏡にベレック式 コンペンセータを用いて応力を測定した. 応力值の計算 にはガラスの光弾性定数を 2.58 として算出した。測定 結果を図一11に示す.これらのグラフに共通した著しい 特徵は，応力の境界が直線的にはっきりして拉り，さら に圧縮応力が表面に向かって大きく減少していることで ある・6.1節で記したように,圧縮応力は変形による緩和 のため表面に向か、若干減少するが，これらの測定結果 は理論的考察の結果より著しく減少している.最大応力 值は温度とともにかなり減少しており，電解による場合 も自然拡散によるイオン交換強化と同様, 歪緩和がかな り影響していることがわかる. $430^{\circ} \mathrm{C}$ の場合に得られる 応力值は, $360^{\circ} \mathrm{C}$ の場合に比べ約半分に減少している. なお，この図では， $360^{\circ} \mathrm{C}$ と $380^{\circ} \mathrm{C}, 400^{\circ} \mathrm{C}$ と $430^{\circ} \mathrm{C}$ は それぞれ同程度の通電量であるため，イオン交換層の深 さは等しくなっている. 前者ではほぼ $3.0 \mathrm{coul} . / \mathrm{cm}^{2}$, 後 者では $7.5 \mathrm{coul} . / \mathrm{cm}^{2}$ である。

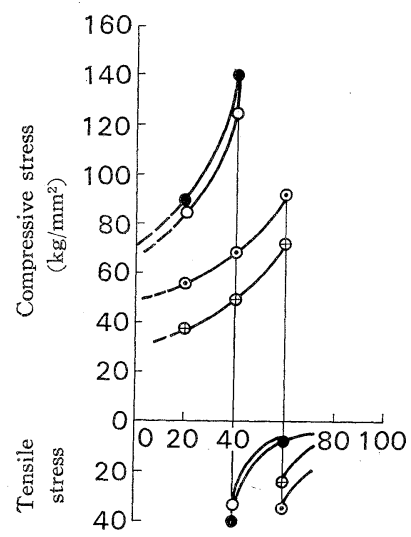

Depth from glass surface $(\mu)$

- $360^{\circ} \mathrm{C} \bigcirc 380^{\circ} \mathrm{C} \odot 400^{\circ} \mathrm{C} \oplus 430^{\circ} \mathrm{C}$

Fig. 11. Stress profiles measured by polarizing microscope and Berek compensator. 


\section{3 曲率から求めた応力值}

片面にイオン交換したことにより 弯曲を生じたガラス板の曲率は, Newton's ring の測定から求めた. 測定方法は, 光源にナトリウム・ラン プを用い，ここから出たナトリウム D 線を half mirror により optical flat の上に置かれたガラス試料にあ て，そのとき生ずる Newton's ring の径を万能投影機で 10 倍に拡大し て測定した。

ガラス試料の曲率半径を $R$, ガラ スと optical flatの接点を原点にと り, Newton's ring の半径を $x$, そ の位置でのガラス試料と optical flat との間の 距離を $y$, ナトリウム $\mathrm{D}$ 線の波長を入とすると(図-12 参 照), Newton's ring はガラス試料 と optical flatの間の距離が $\lambda / 2$ の 整数倍の所で生ずるから，

$$
y=\frac{\lambda}{2} \cdot n(n \text { 注整数 })
$$

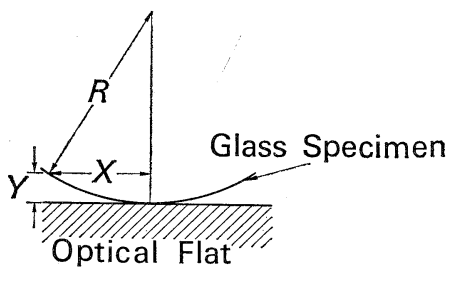

Fig. 12. Relation between $R, x$ and $y$.

畄-12より

$$
R^{2}=x^{2}+(R-y)^{2}
$$

この式に (14) 式を代入し $(n \lambda / 2) \ll R よ り$,

$$
x^{2}=n \lambda R
$$

故に, Newton's ring の半径の 2 乗を縦軸に, ナトリウ ム $\mathrm{D}$ 線の波長の整数倍を横軸にとり，測定值をプロッ トすると直線が得られ, その直線の傾きから曲率半径 $R$ が求まる. Newton's ring の半径の測定は 2 方向に対 して行ない, その各々から求めた $R$ の平均值を応力值 の算出に使用した.

こうして求めた曲率半径 $R$ の值を，(10）と（13）式 に代入して得られた圧縮応力值を表-1に示す.ここで， 交換層の厚みは, 実験前後の重量差から求めた計算值で ある. 試料番号の $C$ 注径約 $5 \mathrm{~cm}$ 円形板, $P$ は $5 \mathrm{~cm}$ 角 板である、また，計算に用いたヤング率とポアンン比の 值は，それぞれ $E=7100 \mathrm{~kg} / \mathrm{mm}^{2}, \nu=0.25$ とした. 表一 1 をみを; 曲率から求めた応力值は $110 \sim 160 \mathrm{~kg} / \mathrm{mm}^{2}$ と大きな值であり，高温になるにつれて若干小さくなる 傾向を示すが，それほど大きな応力緩和はみられない.

\begin{tabular}{|c|c|c|c|c|c|c|c|}
\hline $\begin{array}{c}\text { Specimen } \\
\text { No. }\end{array}$ & $\frac{\begin{array}{l}\text { Temper } \\
\text { time of }\end{array}}{\left({ }^{\circ} \mathrm{C}\right)}$ & $\frac{\text { eatment }}{(\mathrm{min})}$ & $\begin{array}{c}\text { Exchanged } \\
\text { layer } \\
(\mu)\end{array}$ & $\begin{array}{c}\text { Curvature } \\
R \\
(\mathrm{~cm})\end{array}$ & $\begin{array}{c}\frac{(2 h)^{2}}{R} \times 10^{4} \\
(\mathrm{~cm})\end{array}$ & $\begin{array}{c}\sigma_{\max } \\
\left(\mathrm{kg} / \mathrm{mm}^{2}\right)\end{array}$ & $\begin{array}{c}\sigma_{\text {int }} \\
\left(\mathrm{kg} / \mathrm{mm}^{2}\right)\end{array}$ \\
\hline$C-11$ & 460 & 10 & 34 & 228 & 3.4 & 140 & 150 \\
\hline $\mathrm{C}-2$ & " & 30 & 90 & 111 & 7.9 & 130 & 140 \\
\hline C- 7 & $"$ & 15 & 54 & 170 & 4.7 & " & " \\
\hline C-14 & " & " & 53 & 165 & $"$ & $"$ & $"$ \\
\hline$C-15$ & 430 & 10 & 24 & 364 & 2.4 & 160 & 160 \\
\hline$C-8$ & " & 20 & 44 & 196 & 3.9 & 140 & 140 \\
\hline$C-9$ & $\Rightarrow$ & 10 & 48 & 179 & 4.3 & " & $"$ \\
\hline$C-16$ & " & 30 & 76 & 138 & 6.5 & 130 & $"$ \\
\hline $\mathrm{C}-17$ & $"$ & 40 & 89 & 119 & 7.6 & 120 & 130 \\
\hline C -4 & $"$ & " & 98 & 112 & 8.1 & $"$ & $"$ \\
\hline$C-6$ & " & 60 & 129 & 78 & 10.4 & $"$ & " \\
\hline$C-36$ & 380 & 31 & $50^{\circ}$ & 176 & 4.7 & 140 & 150 \\
\hline $\mathrm{C}-37$ & " & 65 & 73 & 120 & 6.8 & $"$ & $"$ \\
\hline $\mathrm{C}-38$ & " & 90 & 93 & 101 & 8.4 & 130 & 140 \\
\hline $\mathrm{C}-39$ & " & " & 89 & 103 & 8.7 & 140 & 150 \\
\hline$C-40$ & " & 100 & 103 & 92 & 9.7 & 110 & 120 \\
\hline$P-8$ & 400 & 90 & 114 & 85 & 9.7 & 120 & 130 \\
\hline$P-9$ & $"$ & " & 108 & 84 & $"$ & 130 & 140 \\
\hline$P-10$ & $"$ & " & 147 & 63 & 13.0 & 120 & " \\
\hline P-12 & $"$ & " & 99 & 96 & 8.7 & 130 & $"$ \\
\hline
\end{tabular}

Maximum compressive stress and intrinsic compressive stress calculated from the curvature of glass.

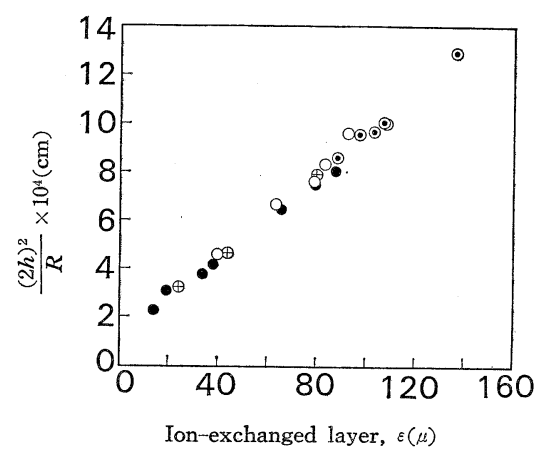

○ $380^{\circ} \mathrm{C} \odot 400^{\circ} \mathrm{C}, 430^{\circ} \mathrm{C}, \oplus 460^{\circ} \mathrm{C}$

Fig. 13. Relationship between $\varepsilon$ and $(2 h)^{2} / R$.

同様に, 処理時間が短く交換層の厚みが小さいと応力值 は大きくなり，応力緩和の時間依存も示しているが，処 理時間とこの応力緩和との関係は余りはっきりしていな W.

$(2 h)^{2} / R$ と交換層の厚さ $\varepsilon$ との関係をグラフにした ものを図-13に示す. これをみると， $(2 h)^{2} / R$ と $\varepsilon$ は ほぼ直線関係を示しているが，これは，(11)式より， $\varepsilon / 2 h \ll 1$ では,

$$
\begin{aligned}
& \frac{(2 h)^{3}}{R}=\frac{6 \phi_{0}}{E}\left(2 h \varepsilon-\varepsilon^{2}\right) \simeq \frac{6 \phi_{0}}{E} \cdot 2 h \varepsilon \\
& \therefore \frac{(2 h)^{2}}{R} \propto \varepsilon
\end{aligned}
$$

が成り立つことを表している．このとき，実験温度が変 れば， $\phi_{0}$ が変化して (16) 式の比例定数は異る值を持つ であろ5。しかし，図-13では異る温度に対してもすべ てほとんど同一直線上にのり, 温度に対して insensitive である、これは，先に述べた応力の計算值の結果と同じ 
である。

\section{7. 討論}

4 節で述べたように，電解によるイオン交換でもガラ スの全部の $\mathrm{Na}^{+}$イオンは外部からの $\mathrm{K}^{+}$イオンで置換 されないことがわかる。しかも， $\mathrm{K}^{+}$イオンの占有率は ほぼ自然拡散によるイオン交換の場合とほとんぞ同じで ある.このことから, ガラスの電気伝導は, ガラス中の すべての $\mathrm{Na}^{+}$イオンが携わるのではなく，その中の数 \%は全く関与していないといえる.これは，R.H. Doremus の主張する分相ガラスに㧍ける ideal phase mo$\mathrm{del}^{8}$ ) (すなわち, Pyrex glass 中では, $95 \%$ の $\mathrm{Na}^{+}$イ オンを含む sodium borosilicate と残りの $\mathrm{Na}^{+}$イオン を含む high silica phase に分れており，前者の phase 中の $\mathrm{Na}^{+}$イオンは動き易く, 伝導に大きく寄与する) のようなものが普通板ガラスにも成り立っている，ある いは，並河，中島のいう 導電路モデル9（荷電粒子は制 限された道筋しか通れないという考光）において，導電 路上にある $\mathrm{Na}^{+}$イオンは伝導に寄与するが，導電路外 にある $\mathrm{Na}^{+}$イオンは伝導に寄与せず，したがって $\mathrm{K}^{+}$ イオンとは置換されない，ということに起因するのかも しれない。

偏光顕微鏡による応力分布の測定結果では応力は表面 に向かって大きく減少している.この原因は,ガラス中で の $\mathrm{K}^{+}$イオンの強制移動のために, network 中の cavity が流動変形により押し拡げられて応力緩和が生じるが， 早く置換された場所は緩和する時間が長いため, 緩和の 度合いが表面に近い場所ほど大きくなったと考えられ る. 流動変形による緩和は, ガラスの歪点以下の温度 で, ガラス中の $\mathrm{Na}^{+}$イオンを $\mathrm{K}^{+}$イオンで置換し, 再 びこの $\mathrm{K}^{+}$イオンを $\mathrm{Na}^{+}$イオンで交換すると（自然拡 散によるイオン交換でも，あるいは電解によるイオン交 換でも)，その表面にはクラックが発生するという現象 からも十分考えられる。

最大圧縮応力值は, 偏 光 顕微鏡による測定值では, $430^{\circ} \mathrm{C}$ で約 $70 \mathrm{~kg} / \mathrm{mm}^{2}, 360^{\circ} \mathrm{C}$ では約 $140 \mathrm{~kg} / \mathrm{mm}^{2}$ とほ ぼ 2 倍も大きくなっている。ところが，曲率から求めた 最大応力值は, $380^{\circ} \mathrm{C}$ で約 $130 \mathrm{~kg} / \mathrm{mm}^{2}, 460^{\circ} \mathrm{C}$ でも約 $130 \mathrm{~kg} / \mathrm{mm}^{2}$, であり，顕微鏡による測定值と比べると， 高温では約 2 倍も大きい. このように, 曲率から求めた 応力值が高温でも高い值を示すのは, 歪緩和による応力 減少がガラスの変形に影響を及ぼさないためであろう。 すなわち，ガラスの変形は初期の高応力によって生じ， 応力が緩和しても，変形によって生じる応力自体も緩和 するので,変形は元に戻らないのであろう．したがって， 応力緩和が起る場合には, 曲率の測定から応力を求める ことはできないといえる．もし，曲率半径の測定誤差が 原因とすれば，低温でも同様の差を示すであろう。ヤン
グ率の温度変化を考慮しても, 約 $0.3^{\circ} \mathrm{C}^{-1}$ 程度であっで, それほど影響を与えない，また，応力分布が緩和により 表面に向汃減少していることを考慮して計算した場合 には，応力值は先の結果よりさらに大きくなる.

\section{8. 総 括}

電解により 普通板 ガラスの片面に $\mathrm{Na}^{+} \rightarrow \mathrm{K}^{+}$イオン 交換を行なわせた. そのときのガラス中の $\mathrm{K}^{+}$イオン濃 度を炎光分析で測定した結果, ガラス中のアルカリイオ ンはすべて $\mathrm{K}^{+}$イオンで置換されず，その值は $93 \%$ で あった. したがって，すべてのアルカリイオンは，ガラ スの電気伝導に寄与しないと考えられる。

電解中のガラスの比抵抗変化は, 侵入した $\mathrm{K}^{+}$イオン 層の厚さと直線関係にあり, $\rho=\rho_{0}+\rho_{1} \varepsilon / L$ の式をよく 満足した. ここで， $\rho_{0}$ と $\rho_{1}$ はそれぞれガラス中の $\mathrm{Na}^{*}$ イオンと $\mathrm{K}^{+}$イオンの拡散に関係した比抵抗であり， は交換層の厚み， $L$ はガラス板の厚みである。また， $\rho_{0}$ と $\rho_{1}$ の温度依存性から，それらイオンによる伝導の活 性化エネルギーを求めた.さらに， $\rho_{1}$ の值から Einstein の式を用いて板ガラス中の $\mathrm{K}^{+}$イオンの拡散係数を概算 した.

偏光顕微鏡による応力分布の測定結果では, 圧縮応力 は表面から内部に向か、著しく増加し，交換層の境界面 で絶壁状に引張応力に変化している. 最大圧縮応力值は： 処理温度とともにかなり大きく変化して㧍り， $430^{\circ} \mathrm{C}$ の 場合の值は $380^{\circ} \mathrm{C}$ における值の約半分であった.

板ガラス試料は，片面だけイオン交換されたことによ： り，応力の釣り合いから球面状に弯曲する.この変形の， 曲率を Newton's ring から測定して応力を計算した。 この場合の最大圧縮応力の計算值は, 処理温度が変化し てもほとんど一定であり，応力緩和の影響はみられなか った。したがって，応力緩和が存在するような場合に は，板の変形 (弯曲) から応力を求めることはできない ことがわかった。

\section{文献}

1) F.M. Ernsberger, Glass Ind. 47[10] 542 (1966).

2) D.L. Rothermel, J. Am. Ceram. Soc. 50, 574 (1967).

3）寺井良平, 北岡猛志, 上野 力. 案協 77 [3] 88 (1969)。

4) E.L. Williams, Glass Ind. 43[8] 440 (1962).

5）例光ば, 原 守久, 旭硝子研報 1，259 (1951).

6) B.A. Boley and J.H. Weiner, "Theory of Thermal Stresses", p. 277 (1960), John Wiley and Sons, New York. London.

7) S. Timoshenko and S. Woinowsky-Krieger, "Theory of Plates and Shells",Second Edt., p. 33 (1950), McGraw-Hill, New York.

8) R.H. Doremus, Phys. Chem. Glasses 9, 128 (1968).

9）並河 洋, 中島達二, 第 4 回ガラ ス 部会討論会講演要旨 集, p. 13 (1968).

(11/24/1969 受付) 